Medical History, Supplement No. 10, 1990, 82-101.

\title{
A TRIAL OF THE BATH WATERS: THE TREATMENT OF LEAD POISONING
}

\author{
Audrey Heywood
}

The Reverend Joseph Glanvill, FRS ${ }^{1}$ was expressing a contemporary view of the aims of the Royal Society when in 1668 he wrote, "We must seek and gather, observe and examine and lay up in bank for the ages to come. This is the business of the experimental philosophers." These words could be applied to the foundation of the Bath General Hospital, which opened in 1741, where it was hoped that by means of a "trial of the waters" it would be possible to show that Bath spa therapy as then practised was effective against many diseases. This was possibly the first extensive trial of any medical therapy.

It is commonly assumed that spa therapy has only a placebo effect; that the pleasurable activity of immersion in warm mineral water has social and psychological benefits, but no physiological value. But the records of the Bath Hospital show that Bath spa therapy was an effective treatment for one common and chronic condition, the paralysis that occurs as the result of chronic lead intoxication (colica pictonum). Chronic lead poisoning is a characteristic disorder, presenting with severe abdominal colic and constipation followed by a loss of function of the limbs without loss of sensation. It has been possible, therefore, to use the information collected in the records of the Bath Hospital ${ }^{2}$ from 1760 to 1879 to identify cases and to show that Bath spa therapy was indeed of value in its treatment. ${ }^{3}$ During this period of 120 years, 3,377 patients (6.9 per cent of the total admissions) were admitted to the hospital with a diagnosis of paralysis due to lead poisoning; 45.4 per cent of these

Audrey Heywood, M.B., Ch.B., Research Fellow, Department of Renal Medicine, Southmead Hospital, Bristol BS10 5NB.

\section{ACKNOWLEDGEMENTS}

I thank the Bristol Kidney Fund for its financial support, and acknowledge the encouragement that I have received from Dr J. Campbell McKenzie and Dr A. H. Waldron. I also thank Mr C. Quinnell for access to the Bath Hospital records.

\footnotetext{
${ }^{1}$ Joseph Glanvill, Plus ultra: the progress and advancement of knowledge since the days of Aristotle, London, James Collins, 1668, p. 91.

2 The records of the Bath Hospital are now in the Royal National Hospital for Rheumatic Diseases in Bath. Those used in the present study comprised: the Annual Reports (1741-1890); Minute Books over the same period but especially that for 1754; and the Referral Register for 1751-58, the only one still in existence.

${ }^{3}$ Paralysis due to chronic lead poisoning was chosen as the disorder to be studied as patients with this condition made up an average of 8 per cent of those admitted to the hospital during the period $1760-1879$. Very common from the sixteenth to the end of the nineteenth century, this disorder's causal or aetiological agent is a metallic ion that does not change or mutate over time. The flaccid, peripheral paralysis occurs after an attack or attacks of severe spasmodic abdominal pain: this too is characteristic. It is therefore possible to accept a contemporary judgement that a paralysis had existed and was cured.
} 


\section{A trial of the Bath waters}

patients were later discharged as cured. ${ }^{4}$ By using modern immersion techniques it is possible to indicate how these cures may have been achieved.

As patients with paralysis due to lead made up 8 per cent of the patients treated in the hospital, Dr Rice Charleton ${ }^{5}$ was able to give a concise and knowledgeable description of the colica pictonum in the second edition of his Three tracts on Bath Water, published in 1774.

In consequence of a most obstinate costiveness attended with exquisite pain in the bowels, upon the constipation being removed and the pain diminished, the patient loses the use of his limbs. The arms and hands most commonly. Rheumatic pains sometimes attack the limbs before they become paralytic... Lead we know is remarkably productive of this complaint ... The colic which gives rise to this species of palsy, was not unknown to the ancients. It was twice mentioned by Paulus Aegina.

This syndrome or pattern of symptoms had been described by Citesius, Cardinal Richelieu's physician, in 1616 . He called it the colica pictonum. ${ }^{6}$ Although there had been widespread epidemics of colics followed by palsy for centuries there was no clear idea of the cause of this disorder. It was attributed to anything from metallic poisons or unresolved fevers; to over-indulgence in acid wines, high living, or passions of the mind. It was not until 150 years later that Sir George Baker's classic works on the Devonshire Colic, ${ }^{7}$ published in 1768 , established that lead was the cause of the colica pictonum and that the Devonshire Colic, "painters' palsy", and the West Indian "dry gripes" were all the same disease. The paper in which he quoted the records of the Bath General Hospital finally brought the danger of chronic lead poisoning to the public eye. $^{8}$

\section{LEAD POISONING RECOGNIZED AND UNRECOGNIZED: ITS TREATMENT IN BATH}

Lead poisoning was a widespread but undiagnosed problem from Roman times until the end of the nineteenth century. A large proportion of any population using lead pipes to carry soft water; lead-glazed earthenware containers for food and drink; cooking pots tinned with the usual mixture of tin and lead; pewter plates and tankards; and lead-lined sinks and storage boxes could readily acquire a significant lead load. Cosmetics were often lead-based as were food colorants, and lead salts were frequently used medicinally.

For many people this level of poisoning would have caused tiredness, headaches,

\footnotetext{
${ }^{4}$ It was stated in the Narrative of the efficacy of the Bath Waters in various kinds of paralytic disorders admitted into the Bath Hospital, 1775-1785, (Printed by B. R. Cruttwell for the Hospital, Bath, 1787, p. viii) that "it is a rule with the physicians never to set down any patient as cured, whilst he has any degree of the disorder for which he was admitted remaining." It is therefore reasonable to accept the reliability of the data collected in the Annual Reports from 1760 to 1880 in the case of paralysis due to lead.

${ }^{5}$ Rice Charleton, Three tracts on Bath Water, 2nd ed., Bath, Wm. Taylor, 1774, Tract 2, p. 77-9.

${ }^{6}$ Francis Citois, De novo et populari apud Pictones dolore colico bilioso diatriba, Paris, 1639. Quoted by Joseph Eisinger, 'Lead and wine: Erbhard Gockel and the colica Pictonum', Med. Hist., 1982, 26: 279-302.

${ }^{7}$ George Baker, 'An inquiry concerning the cause of the endemic colic of Devonshire' (London, 29 June 1767), Med. Trans. Coll. Phys. Lond., 1768, 1: 175-256; idem, 'An attempt towards an historical account of that species of spasmodic colic distinguished by the name of the colic of Poitou', ibid., pp. 319-63.

${ }^{8}$ Idem, 'An examination of several means by which the poison of lead may be supposed to gain admission into the human body, unobserved and unsuspected', ibid., pp. 257-318. Baker's three papers were reviewed by H. A. Waldron, 'Devonshire Colic', J. Hist. Med., 1970, 25: 383-413.
} 
and a vague feeling of malaise, but others would be more seriously affected. These were the people who added to their base load of lead small but repeated doses of lead from occupational exposure or lead-adulterated alcohol. Lead is soluble in such weak acids as the acetic acid formed when alcohol is exposed to the air; so alcohol might easily become contaminated. This contamination may occur incidentally during distillation, when lead is leached out of soldered joints or base-metal condensers, or accidentally, if sour cider or apple must comes into contact with the lead which was often used to repair cracks in the cider press. Adulteration could also occur if the cider was stored in lead-glazed earthenware containers. Poor or acid wines were sometimes adulterated deliberately, in the Roman tradition of using lead acetate as a sweetener, improver, and fungicide. ${ }^{9}$ This more serious exposure to lead resulted in severe colic, constipation, and weakness or paralysis of the limbs. Further intake could result in profound wasting, convulsions, coma, and death.

Gout ${ }^{10}$ and reduced fertility may also result from chronic lead intoxication. These are not discussed here as barren women were not considered to be suitable "objects of charity" at the Bath Hospital and the poor did not present with gout there until 1865.

The connection between Bath spa therapy and the colica pictonum had been made long before the foundation of the hospital in the eighteenth century. The Romans, who are known to have drunk lead-adulterated wine, ${ }^{11}$ enjoyed using the Hot Baths in Bath but there is no evidence to show that they recorded the therapeutic effects of bathing there, although the presiding goddess Minerva was credited with curative powers. From the Middle Ages onwards, however, there was a growing awareness that the mineral waters in Bath cured some cases of paralysis. In 1568, Dr William Turner, the Dean of Wells, published $A$ booke of the natures and properties, as well of the bathes in England as of other bathes in Germanye and Italye-very necessarye for all these persons that can not be healed without the helpe of natural bathes. ${ }^{12}$ This was the first book to be published in English about the Bath waters. In it, Turner listed many conditions reputed to have been treated successfully in the baths in Germany and Italy and that, theoretically, should respond to treatment at Bath. He advised the use of the waters for treating such injuries as the "brusing that cummeth by falling or beating", for "Grene or new wounds", and "Old wounds falsely healed", but also advocated their use for conditions that may have resulted from chronic lead poisoning. These include severe constipation: "The vayne appetite of going to stoole / When a man can do nothing when he cummeth there", or "The hardnes and binding of the bellye / when as a man can not go to the stoole without Physics". The palsy ${ }^{13}$ was also mentioned, unqualified or "when as a man is quite num all the parts

\footnotetext{
${ }^{9}$ Eisinger, op. cit., note 6 above.

${ }^{10}$ B. T. Emmerson, 'Chronic lead nephropathy', Kidney Int., 1973, 4: 1-5.

11 J. O. Nriagu, 'Saturnine gout amongst Roman aristocrats', New Eng. J. Med., 1982, 308(11): 660-3.

${ }^{12}$ Cologne, Arnold Birckman, 1568, pp. iv-v.

13 John Quincy, Lexicon Physio-Medicum, 10th ed., London, J. Osborne, T. Longman, 1787, p. 629. In 1730 "Palsy" was defined as a "privation of motion or sense of feeling or both proceeding from some cause below the cerebellum, joined with a coldness, softness and flaccidity and at last wasting of the parts." In modern terminology this description fits that of a peripheral neuropathy, i.e., the lesion occurs in the peripheral nerve or in the neuro-muscular synapse. In 1780 William Cullen's Nosology, published in Latin in Edinburgh, defined palsy as a loss of power of voluntary motion. Both definitions were included in the 1787 edition of Quincy's Lexicon.
} 
of his body / and hath not ther moving nor fealing"; the "Cramps and drawing together brawnes and synnewes or the streching furth to muche of the same" (a flaccid paralysis). The colic, "Wormes in the bellye", and the "goute" could also be treated. The other main group of "sicknesses which may be healed by these bathes" were those that resulted in infertility or abortion, "Barunnes of man or woman" and "The casting of children out / before the dewe tyme appoynted by nature". These conditions may also result from consuming food or drink adulterated with traces of lead.

As early as the beginning of the sixteenth century Bath had a well-established reputation for curing people with paralyses and its collection of discarded crutches had become legendary. ${ }^{14}$ But some cases did better than others, particularly those patients with paralyses that followed attacks of severe, griping abdominal pain. They called this the "Palsy after the Colic", meaning in this instance a "privation of motion". 15 In 1713 Dr Robert Peirce ${ }^{16}$ published his Memoirs of 60 years of practice as the senior physician in Bath. He recorded and classified most of the cases he had seen from the middle of the seventeenth century onward. Because he was so familiar with many types of paralysis, he was able to differentiate the "Palsy after the Colic" from the paralyses that were the "consequence of Apoplexes, Epilepsies or Convulsions" and identified the former as the colica pictonum. Of the "Palsy after the Colic" he wrote, "I find no one Distemper more frequent amongst my Adversaria, nor in none more eminent recoveries than in this, or persons thus disabled to have been restored by the assistance of the Bath and the Bath waters." His patients came from as far afield as the West Indies, Ireland, the Channel Isles, and East Anglia. One the Reverend Mr Pilkington came from Lincolnshire in May 1666 with his arms "hanging like flayls"; he could neither feed nor dress himself. "Although he was a Clergyman the disease had made a Quaker out of him." He could not doff his hat in greeting to anyone until he had bathed and drunk the water for six to seven weeks. After that the "first instance of his being better (with much joy to shew his improvement) coming to my house he put off his hat to me."

In 1728 John Wynter ${ }^{17}$ published a letter he had written to Dr Freind, a distinguished London physician, in which he mentioned,

the great crop of Paralytics that daily spring up amongst the Tradesmen, from the Necessity of their ordinary employments, Colour grinders, Pewterers and Chemists. The palsies of such tradesmen never fail of a cure by Bathing, and that not barely a first, but a second, nay third time of their unavoidable Calamity.

He also pointed out the "vast Import of Palsied from the West Indies"; the "West-Indian scarce ever repents his voyage, if he is suffered to Bathe, notwithstanding his sort of Palsy is a second disease; being the successor of the most painful Colic imaginable."

Amongst workers using lead, including painters, potters, plumbers, and printers, as well as smelters, colic and constipation occurred frequently. These symptoms were

14 Daniel Defoe, A Tour through Great Britain, London, Folio Society, 1983, vol. 2, p. 170.

15 See note 13 above.

${ }_{16}$ Robert Peirce, The history and memoirs of the Bath, London, Henry Hammond, 1713, pp. 83-101

17 John Wynter, Of bathing in the Hot-Baths at Bathe, London, James Leake, 1728, p. 53. 


\section{Audrey Heywood}

treated successfully by the regular use of purges and emetics. Opiates were used if the pain was severe. This regimen was the standard treatment in Europe and the Americas, for the colic and costiveness which occurred very commonly in the rest of the population as well. ${ }^{18}$ If later a paralysis developed, typically in the form of a dropped wrist, this too often responded to the conventional treatments, a bland diet, and removal from the source of lead. Sometimes, however, the paralysis persisted. This was a disaster as the man could no longer earn a living. Some of these apparently incurable cases eventually found their way to the Bath Hospital, frequently many months after the onset of the paralysis, and the cures obtained there must have appeared to be remarkable. In addition to the usual treatments, the Bath mineral waters were used.

A pattern for bathing and drinking the water had gradually evolved. People usually bathed in the morning; since Tudor times the water had been changed daily so the Baths were closed from noon to allow this to take place. The Baths took nine hours to refill. The earlier bathers had the cleaner water. Even so Samuel Pepys ${ }^{19}$ was astonished to find fashionable people bathing in the Cross Bath at five o'clock in the morning. Celia Fiennes ${ }^{20}$ noted on her visit in 1687 that the bathers stood or sat up to the neck in the water. Stone "coushons" were provided for those who found the seats too low. Bathing could last from 30 minutes to several hours, and music and other entertainments were provided to pass the time.

Drinking the water became more acceptable after 1650 , when a clean supply was provided which came directly from the spring. Peirce claimed that "Advantage has been found by it [drinking the Bath water], especially in the Bilious Cholicks, and the usual Effects of them, Loss of Limbs."21 One to two pints were consumed each morning in divided doses. Sometimes the patients chose to drink much larger amounts, but this was frowned upon.

The reputation of the healing powers of the Bath waters grew throughout the latter part of the seventeenth century, when the journey was uncomfortable and hazardous, and the local accommodation and the Baths themselves were squalid. In spite of this, patients, encouraged by royal patronage of the Baths, came in increasing numbers, and many were cured. Thus, by the beginning of the eighteenth century, the doctors of Bath believed that they had access to a very powerful treatment for several very common chronic disorders; the colica pictonum was one of these.

As it was common knowledge that Bath was the place to go to if you were left with a palsy after an attack of severe colic, the Bath physicians saw many cases. They could recognize this highly characteristic disease, and knew that they could cure many of these patients, but other doctors were doubtful of these claims. The doctors practising in Bath had had more opportunities to observe the differing prognoses of the

\footnotetext{
18 The London practice of physic, London, G. Robinson, R. Baldwin \& J. Bew, 1778, p. 189.

${ }^{19}$ Samuel Pepys, Diary, 13 June 1668. Edited by R. Latham and W. Matthews, London, G. Bell and Sons, 1976, vol. 9, p. 233.

${ }^{20}$ Celia Fiennes, The journeys of Celia Fiennes, ed. C. Morris, London, Cresset Press, 1947, p. 18.

${ }^{21}$ Peirce, op. cit., note 16 above, pp. 253-5, part 2: 'What cures have been wrought by drinking these waters, [chiefly] by God's Blessing on the Conduct and Directions of Robert Peirce.'
} 


\section{$A$ trial of the Bath waters}

paralyses secondary to lead poisoning, compared with those due to such other causes as cerebral vascular accidents or spinal injury. However, Robert Peirce's classification and analysis of the cases seen in Bath, published in 1713, was not given any credence by Richard Mead, the highly influential physician to George II. In his Medical precepts and cautions, published in 1751, Mead wrote that bathing in hot water was prejudicial for all paralyses, and he mentioned Bath specifically. ${ }^{22}$

So more than anecdotal evidence was needed to support the claims for the curative powers of the Bath waters. It was felt that a charity hospital could provide a very good way to do so.

\section{THE FOUNDATION OF THE BATH GENERAL HOSPITAL}

The idea of founding a hospital in Bath to treat those with the chronic diseases that responded to treatment with the Bath waters was first considered about $1711 .^{23} \mathrm{At}$ this time a vast number of "sturdy beggars" threatened to inundate the town and were undoubtedly detracting from the pleasures of the visitors who were paying to take the waters. This problem had arisen as a consequence of an Act of Parliament passed in 1597, by which Elizabeth I gave the "diseased and impotent poor of England" the free use of the baths of Bath. Large numbers of poor cripples came to the city. Although they were expressly forbidden to beg, many became "more intent on the alms which fortune might grant them from the purses of the charitable and opulent who congregated at the springs than upon anything else."

In 1714, as a result of local pressure, the Act was repealed, but the beggars remained. In 1716, a committee was formed to consider other ways of dealing with this pressing problem. The idea of a hospital to deal with genuine "objects of charity" was again mooted, but the committee were unable to open a list of subscribers until the autumn of 1723 . Even then only $£ 27312 s$. $1 d$. was collected. Various attempts to acquire gifts of land on which to build the hospital were also frustrated.

During the years between 1716 and 1737 the aims of the charity were modified. The original plan was to identify the number of true cripples in the city and then to consider what accommodation was required to house the genuinely deserving poor. This would enable the disabled to stay long enough to benefit from the prolonged treatment required to obtain a cure, which it was felt could only be obtained in Bath. The blatant beggars could then be considered as vagrants and sent from the city. Later, however, the plan was developed into one of mutual aid. In return for treatment and free accommodation, these "charitable objects" would enable the physicians to set up a "trial of the waters". The founders had realized that if the hospital could be set up in such a way that the treatments could be regulated, carefully recorded, and their results published, the therapeutic properties of the Bath waters could be established in a scientific manner. A very satisfactory arrangement for all concerned.

\footnotetext{
${ }^{22}$ Richard Mead, Medical precepts and cautions, first English ed., London, Brinsley, 1751, p. 69.

${ }^{23}$ Randle W. Falconer, in An Account of the Bath General or Mineral Hospital, 2nd ed., Bath, R. E. Peach for the President and Governors of the Bath General Hospital, 1869, pp. 1-11. Details of the development of the Bath General Hospital were given by Dr Falconer in this book, which was the first official history of the hospital covering the period from 1716, when Lady Elizabeth Hastings and Mr Henry Hoare first proposed the founding of the hospital, until 1840.
} 
The first attempt to set up a hospital in Bath failed from lack of support, but the second appeal, launched in 1737, was successful. Social attitudes to charity had changed and the new plan offered positive advantages to the donors, as Roy Porter has pointed out in his essay on 'The gift relationship'. ${ }^{24}$ By 1730 the Reverend Alured Clarke of Winchester had come up with the idea of a charity hospital to be funded in a way that tapped the new wealth of the manufacturers and merchants by offering them the opportunity of achieving virtue and gentlemanly status by joining the aristocracy in charitable giving. The Reverend Clarke also showed that, by supporting a charity hospital with regular subscriptions, the subscribers could not only, as governors, maintain financial control of the hospital, they could provide the necessary medical care for their increasingly skilled, wealth-producing work-force. It was calculated at the time that the death of a working man represented a capital loss of $£ 200$ to the community, whereas the average cost of inpatient treatment was $£ 312 s$. per head. ${ }^{25}$

The charity hospital or infirmary was therefore a most useful device from which both the donors and the recipients of the charity obviously benefited. The poor patients, the "objects of charity" were provided with an alternative to quack treatments that were likely to disable them permanently. Workers were returned to work as quickly as possible. As the doctors gave free medical treatment they were elevated from tradesmen to gentlemen. This revolutionary idea of dispensing charity lead to the foundation of hospitals or infirmaries in Winchester, Exeter, and Bristol by 1735 : in 1760 there were 16 provincial hospitals. ${ }^{26}$

In Bath this formula was modified to serve the interests of the local community. Early in the eighteenth century the town's leading citizens were anxious to find ways to maintain its prosperity. To do this it was necessary to provide convincing evidence of the uniquely therapeutic properties of the Bath waters. So, when in the mid-1730s the provincial voluntary hospital had become recognized as an acceptable and fashionable way to dispense charity, the would-be founders of the Bath Hospital realized that, by modifying the idea, it would be possible to fund the establishment of a charity hospital in Bath. If only those patients with the chronic diseases that were thought to benefit from the use of the Bath waters were admitted it could be used as the means of setting up a "trial of the waters". They would be able to use the hospital to fulfill Glanvill's criteria and thus be able to provide evidence of the therapeutic value of the Bath waters that would be acceptable to the scientific community. The knowledge that if the Bath waters were proved to be therapeutic this would greatly enhance the value of their property and practices in Bath added zest to their endeavours, and increased the scepticism of their detractors.

The appeal for funds to establish the hospital was made in 1737 . This stated that, ${ }^{27}$ "All Physicians will allow that the greatest certainly that can be attained to in the knowledge of the Natures and Virtues of any medicine arises out of the Number of

\footnotetext{
${ }^{24}$ Roy Porter, 'The gift relationship' in Lindsay Granshaw and Roy Porter (eds.), The hospital in history, Wellcome Institute Series in the History of Medicine, London, Routledge, 1989, pp. 150-63.

${ }^{25}$ Ibid., p. 163.

${ }^{26}$ Ibid.

${ }^{27}$ Falconer, op. cit., note 23 above, pp. 91-3. This gives the full text of the address to the public; see also figure 1 here.
} 


\section{A trial of the Bath waters}

Observations of the Effect it has on Human Bodies in different circumstances." Thus, in Bath, the accepted concept of a charity hospital was adapted to enable these observations to be made and recorded.

The World is indeed greatly indebted already to many worthy and learned Gentlemen of the Faculty who have published their Observations on the Bath Waters ... but surely if the Knowledge of the Nature and Efficacy of these Waters could still be rendered more extensive and certain it would be doing great service to every individual Person. Everybody may see therefore how great an Advantage this Hospital may be to the Publick: The sick will be healed, many Parishes eased of the burden of their useless poor Cripples and the Knowledge and use of Bath Waters will be greatly improved to the Benefit of all Succeeding Generations.

It was the wealthy patients with gout that the doctors of Bath were hoping to interest when they set up their "trial of the water". As Lendon Smith ${ }^{28}$ has pointed out, Bath's popularity as a centre of healing had increased steadily after Anne of Denmark's visit in 1616, and the city had begun to provide accommodation and other facilities for its visitors. By the end of the seventeenth century, many of the increasing number of wealthy and important people with gout came to Bath for treatment and incidentally to amuse and indulge themselves. Later, in the early eighteenth century, pleasure, rather than taking the waters, had become the most important reason for the visit. Fashion is notoriously fickle and many people in fashionable society then decided that places such as Brighton or Cheltenham were perfectly suitable as alternative health resorts in which to spend the summer season. It was in an attempt to stem this trend that the foremost citizens of Bath set up the hospital. They hoped to prove, to the wealthy patients with gout, that the Bath waters provided the best hope of relief from their symptoms. However, the doctors were also aware that many of these patients would not be prepared to follow the prescribed treatments until they were proved to be effective. It was to this group, the gouty rich, that the following part of the 1737 appeal for the hospital was directed (figure 1).

Persons of Higher rank are often negligent of their own health and by no means exact in taking their medicines, abstaining from things that hurt them and staying due time as could be wished, and indeed is necessary to give the Physician a sufficient opportunity either of doing them all the services their cases would admit of or of making Observations for the future benefit of others.

Whereas in this hospital every person will be under his government and direction in all circumstances regarding his health so that a few years will furnish more Histories of cases which way be depended on (if the Physicians keep due register of the sick in their care) than any man's practice could have done in an age.

And it is to be hoped that the success which may be reasonably expected from the regularity of these poor creatures may induce others of better condition voluntarily to imitate them in the management of themselves, that they may receive like benefit.

In fact, it was found that there were very few poor patients with gout. This observation was also made by doctors in London and Edinburgh. ${ }^{29}$

\footnotetext{
${ }^{28}$ R. A. L. Smith, Bath, 2nd ed., London, B. T. Batsford, 1945, pp. 45, 52.

${ }^{29}$ Charles Scudamore, On gout \& gravel, 4th ed., London, Longmore, Hurst, Rees, Orme \& Brown, 1823, p. 74.
} 


\section{Audrey Heywood}

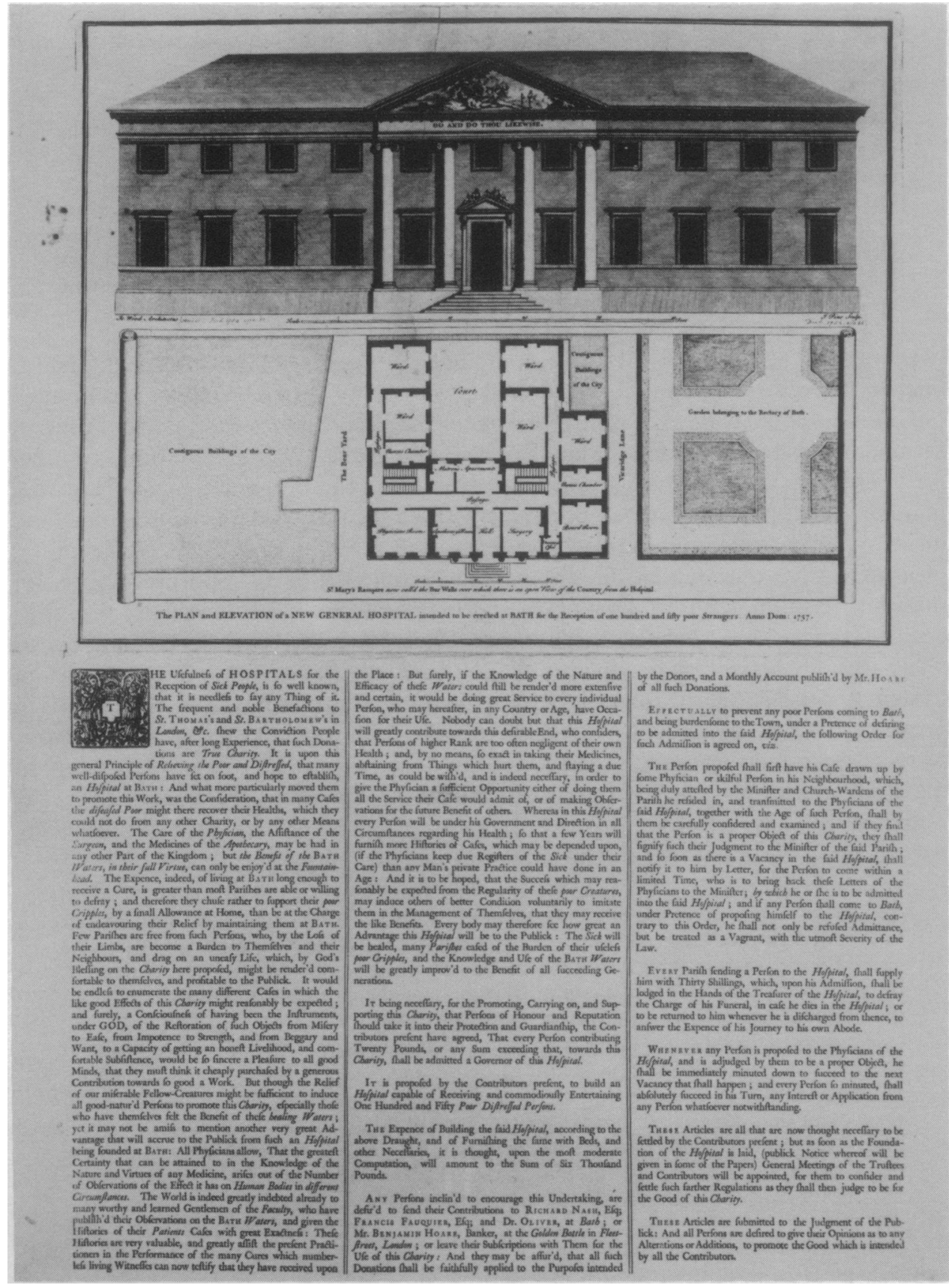

Figure 1: 'The Plan and Elevation of a New General Hospital intended to be erected at Bath for the Reception of one hundred and fifty poor strangers Anno Dom 1737'. A framed copy of this, the architect John Wood's design and the address to the public asking for funds, is displayed in the Board Room of the Royal National Hospital for Rheumatic Diseases, Bath. 


\title{
A trial of the Bath waters
}

This appeal was highly successful. By April 1738, $£ 2,082$ had been raised, a site acquired, the architect John Wood's original plans modified to enlarge the size of the wards, and the philanthropic entrepreneur Ralph Allen had agreed to provide the stone for the buildings. ${ }^{30}$ A year later, $£ 4,268$ had been collected and the Mayor and Corporation of Bath had agreed that the patients in the hospital should have free use of the mineral water together with access to the Hot Bath for bathing. It was then possible to set up the trial.

\section{THE TRIAL OF THE WATERS}

It was thought that by regulating the treatment and allowing ample time to achieve the best possible results, valuable evidence of the efficacy of the Bath spa therapy could be obtained. At that time medical practitioners were notoriously overoptimistic when assessing the results of their own treatments. It was hoped that if the final outcome of treatment was assessed by a committee of doctors, and not only the one in charge of a particular case, no charge of bias could be made. Then by recording these results it would be possible to produce "irrefutable proof" 31 of the curative powers of the Bath waters. It was a very original plan and it appears to be one of the earliest, if not the first, scientific therapeutic trials to be set up.

When the Bath Hospital opened its doors in 1741 the hospital was to treat the deserving sick, so any malingerers or beggars remaining in the city could be sent away as vagrants. Only those patients who would benefit from the special treatment in Bath were to be admitted. A referral letter had to be sent and these letters were vetted by a group of doctors to make sure that the patients were "suitable Objects for Charity". These letters were not always reliable, as Charleton complained: ${ }^{32}$

\begin{abstract}
Whereas the cause and effect of the disease, the age of the patient, the length of time he had laboured under his malady, should have been circumstantially described. If this rule had been observed, we should not have had so many improper persons sent to the hospital: it would have put a stop to the inhumanity of suffering such poor wretches to undergo the fatigues of long and painful journies, to no manner of purpose: and at the same time saved their parishes a very unnecessary expence.
\end{abstract}

The poor accepting treatment agreed to stay until the physicians considered that they were cured or improved as much as possible. In return, the hospital provided accommodation, a good diet, additional medications if needed, and the use of the mineral waters. It was spa therapy sans glamour for the deserving poor. On their discharge these charity patients were examined by the committee of doctors, which decided on the final diagnosis and outcome of treatment. It was clearly stated that no one was to be considered to be cured if any sign of the original disorder remained. ${ }^{33}$ This information was recorded, together with the length of stay and personal details,

\footnotetext{
${ }^{30}$ Falconer, op. cit., note 23 above, p. 11.

31 John Summers, A short account of the success of warm bathing in paralytic disorders, London, C. Hitch \& L. Hawes, 1751 , pp. 24, 4-7.

32 Charleton, op. cit., note 5 above, pp. 10-11.

${ }^{33}$ Narrative of the efficacy of the Bath Waters in various kinds of paralytic disorders admitted into the Bath Hospital, 1775-1785, Published by order of the Committee at the Hospital's Expence, Bath, 1787, p. viii.
} 


\section{Audrey Heywood}

in the Minute Book. It was later copied into the Referral Register, together with a copy of the referral letter. The physicians were expected to keep good records and to publish their findings. Because Bath's was a charity hospital, an Annual Report was published each year. We have evidence from the records kept in the hospital that the protocol laid down was carefully observed. A sophisticated scientific trial, which was also an example of eighteenth-century philanthropy tinged with self-interest, was underway.

On being admitted, the patients were removed from their normal environment and thus from the source of lead pollution. They were provided with adequate fresh food, which was cheap and plentiful in Bath, including home-brewed beer (drinking outside the hospital was banned). They were also given preparatory medication, usually purges, if required. Bathing was carried out three days a week, according to $\mathrm{Dr}$ Summers for over an hour each time, usually in the Hot Bath that had been allocated to the charity patients. Both Dr Summers, ${ }^{34}$ in 1751, and Dr Falconer ${ }^{35}$ in the 1790 s, remarked that they achieved cures more rapidly on the occasions when the cooler Cross Bath was used. In 1830, the hospital got its own bath, whose temperature was kept at about $35^{\circ} \mathrm{C}$. The patients drank one to one and a half pints of water a day, in divided doses. Pumping water on to the paralysed limb was also thought to be helpful in the convalescent stages.

A picture that still hangs in the entrance hall of the hospital was painted by William Hoare in $1742 .{ }^{36}$ It shows Dr Oliver and Mr Pierce the surgeon examining patients together; this was to illustrate the diagnostic committee in action. The very existence of the painting indicates the importance attached to showing the activity of the diagnostic committee, which played an essential part in establishing the reliability of the trial. As Dr Summers ${ }^{37}$ wrote, "When patients are discharged it is what the whole committee sees and examines which is recorded. It is therefore a Testimony to be relied on."

The findings of the committee were recorded in the Minute Book. ${ }^{38}$ The entries give the name, date of admission, diagnosis, and outcome of treatment of the patients to be discharged, together with the initials of the senior physician and surgeon who were present when the Committee assessed the patients' condition prior to discharge. At the bottom of the entry, the number of admissions that had been approved at that meeting were minuted for each meeting.

The Minute Book for 6 April 1754 shows that a Sam Ariss had been admitted on 8 November 1753. He was examined by Dr Abel Moysey and Mr F. Palmer, who gave the diagnosis as colica pictonum and certified that he was cured when discharged in April 1754. Seven other patients were discharged at the same time. Three of these

\footnotetext{
34 Summers, op. cit., note 31 above, p. 12.

35 William Falconer, A practical dissertation on the medicinal effects of the Bath Waters, Bath, R. Cruttwell, 1790 , pp. $69-70$.

36 Roger Rolls, Hospital of the nation, Bath, Bird Publications, 1988, illustration p. ix.

37 Summers, op. cit., note 31 above, p. 4.

38 Minute Book for 1754, see note 2.
} 


\section{A trial of the Bath waters}

patients were "No better" when discharged. They were said to have rheumatism, nervous weakness, and colic with fits respectively. One with sciatica and another with leprosy (any skin disorder was classified as leprosy) were "Much better". Another with palsey was "Better", whilst John Walter had recovered the use of his arm and was cured. The result of treatment could be variable: this is an indication of the honesty and clinical acumen of the medical committee. All the patients were required to stay in the hospital until they were considered to have received the maximum possible benefit from their stay in the Bath Hospital. A further note indicated that three admissions had been approved as well.

Information about individual patients was also recorded, together with a copy of the referral letter, in the Referral Register. From that entry we know that Sam Ariss was a 25-year-old journeyman painter from Birmingham, who had had a weakness in his hands since Christmas 1752 and had been unable to work since then.

Unfortunately there is only one Referral Register still in existence. This contains handwritten copies of the 1,590 referral letters sent to the hospital between 1751 and 1758. The patients were admitted if these letters convinced the Medical Committee that the patients described were suitable "objects for charity" and would benefit from the special treatment only available in Bath. Later the date of admission, and discharge was added together with the final outcome of treatment. Frequently this was initialled by the physician and the surgeon who had examined them.

Table: PATIENTS ADMITTED INTO THE BATH HOSPITAL 1751-1758

\begin{tabular}{lr} 
Total of all cases & 1,590 \\
Patients with paralysis due to lead & 108 \\
\hline
\end{tabular}

$\begin{aligned} & \text { Patients with occupational exposure } \\ & \text { to lead }\end{aligned}$
$\begin{gathered}\text { Patients with paralysis after } \\ \text { colic ("Devonshire Colic") }\end{gathered}$

\begin{tabular}{lcc}
\hline Patients & 31 & 63 \\
Re-admissions & 6 & 8 \\
Admissions & 37 & 71 \\
$\begin{array}{l}\text { Outcome: } \\
\quad \text { Cured }\end{array}$ & $22(59 \%)$ & $30(42 \%)$ \\
$\quad \begin{array}{l}\text { Total improved } \\
\text { Place of origin: }\end{array}$ & $34(92 \%)$ & $66(93 \%)$ \\
$\quad \begin{array}{l}\text { South West } \\
\text { London hospitals }\end{array}$ & 5 & 43 \\
$\begin{array}{l}\text { London } \\
\text { South East }\end{array}$ & 15 & 5 \\
Other & 5 & 15 \\
\hline Average stay in & 6 & 168 \\
\hline hospital (days) & 149 & \\
\hline
\end{tabular}

Source: Referral Register. 


\title{
Audrey Heywood
}

The results of the analysis of this Referral Register (table) show that of the 1,590 cases admitted between 1751 and 1758, 108 had symptoms of chronic lead poisoning. These cases fell into two distinct groups: 37 admissions in which there was evidence of occupational exposure, and 71 admissions in which there was a clear history of a peripheral paralysis following an attack or several attacks of severe colic, but no definite history of lead exposure: the classic symptoms of Devonshire Colic.

The first group was made up of 31 men who worked with lead. There were eleven painters, seven plumbers, four glaziers, and five men engaged in the manufacture of lead, a potter who used lead glazes, a gilder (white lead was used in Italian gilding), and two glass grinders. Six of these workmen were re-admitted during the seven-year period. On discharge, 22 cases ( 59 per cent) were cured and 34 ( 92 per cent) were better. They stayed in the hospital for an average of 149 days.

Examples of the entries in the Referral Register are given below. It seems probable that they were copied from the original referral letters as there are considerable differences in the style in which the history of the patient is presented. The first two entries quoted apply to patients with occupational exposure to lead. The first was referred by a local apothecary, the second by one of the physicians at St Bartholomew's Hospital. ${ }^{39}$

\begin{abstract}
William Hurley of Wellington, Somerset. A Plumber, aged 34 has been several times attacked with the Dry-Belly-Ach. On the Chollics going off, he has been always afflicted with pains in his limbs, and a weakening in his arms that he cannot raise his Hands. The frequent returns of the chollic and the subsequent weakness by incapacitating him from Working at his business have reduced him to great poverty etc.
\end{abstract}

John Cookson Apothecary,

Rich. Marcham 5th September 1753.

Admitted 11 Sept. 1753. Cured. Discharged 17 April 1754.

A Patient 218 days

On 3 May 1756 William Hurley humbly desired re-admission, having a return of his former disorder. He was re-admitted on 27 May 1756 and discharged cured on 13 October of the same year.

Twenty of these lead workers came from London or the South East of England. Fifteen had already been admitted to one of the London hospitals but had not responded to the treatment there. They were referred to the Bath hospital as "incurable", but after treatment in Bath eight were cured and the other seven were said to be improved. These results support the view that the treatment in Bath had something special to offer, as in London they would also have been removed from exposure to lead, and given purges, emetics, and a bland diet, apparently to no avail.

This letter, from one of the doctors at St Bartholomew's Hospital, is more concise: $^{40}$

${ }^{39}$ Referral Register, see note 2, pp. 65, 137.

40 Ibid., p. 134. 
James Buxton of the parish of Higham in the County of Norfolk. 25 years old, by trade a Painter. He has lost the use of his hands five months ago. He has been an In-patient at St. Bartholomew's Hospital for some time and has been advised by the Gentlemen of the Faculty there to try the Bath Waters. signed William Pitcairn.

Admitted 21 April 1756 Discharged 22nd December 1756. Much Better.

A patient for 246 days.

Of the other group of 71 admissions (63 patients) that presented with the classic symptoms of the Devonshire Colic, 43 (60 per cent) came from the South West. They stayed, on average, longer in the hospital (168 days) compared to the cases due to occupational exposure, and a smaller proportion (42 per cent) of these cases were cured, although 93 per cent were improved.

These cases often gave a history of long standing if intermittent attacks of colic, progressing eventually to paralysis of the limbs.

James Blake of Lymington, Hampshire. ${ }^{41}$ For some years past has been greatly afflicted with Bilious colic. In the Begining of May last was seized with a violent fitt, attended with spasms of the stomach and bowells. Excessive pains of the same, Great sickness, perpetual vomitting and costiveness. It was near a fortnight before the symptoms began to decline, but when he found himself relieved from these dreadful sufferings he was suddenly deprived of the use of his hands and feet, and remains so at this time.

Harry Hackman

Admitted 19 Oct. 1756. Disch. 27th April 1757. MUCH BETTER A patient for 188 days. A. M. [Dr Abel Moysey] H. W. [Mr Henry Wright] He was readmitted 4th November 1758 Discharged Much better 12th April 1759

In 1760 Dr Rice Charleton was able to begin classifying the results. ${ }^{42}$ They had already fallen into six groups: ${ }^{43}$ Cured, Much improved, No better, Improper (unsuitable for treatment with the Bath waters), Irregular (patients discharged before treatment was completed, for misbehaviour, or at their own request), ${ }^{44}$ and Dead.

41 Ibid., p. 149.

42 It is presumed that the classification of cases into diagnostic categories on discharge was done by Charleton. William Oliver resigned in May 1761, and left it to Charleton to publish his case histories posthumously in the Tracts, (op. cit., note 5 above), in 1774.

${ }^{43}$ The records published in the Annual Reports became formalized in 1760. It was recognized that it was important to define the categories of outcome of treatment on discharge very clearly if the results were to be believed to be reliable. The Narrative (op. cit., note 33 above, p. viii) states that "it is a rule with the physicians never to set down any patient as cured, whilst he has any degree of the disorder for which he was admitted remaining: if the slightest degree be left, he is only set down as much better. None are ever discharged as much better, unless their admendment be very considerable. In doubtful cases, it is usual to attribute too little, rather than too much, to the efficacy of the waters ... All the patients, after being minuted to be discharged by the physician who attends them are examined by the physicians and surgeons at large belonging to the hospital. This is done in order that any mistake in the report of the state of the patient's health may be corrected, previous to such a report being registered. Lastly, all the patients to be discharged are produced before the committee where they are again examined, and particularly as to their state of health at the time of their admission, in order to compare it with the state in which they appear at their discharge."

44 Charleton in the second of his Tracts (op. cit., note 5 above, pp. 10-15) defined the terms "Improper" and "Irregular". "The term Improper [to be admitted] was used for those who had been misrepresented by those who drew up their cases at their place of abode." Those improper for continued treatment were either 
Charleton grouped the cases into seven diagnostic categories: Rheumatism, Paralysis, Leprosy or skin disease, Lameness, Hip cases, Jaundice, and Vertebral deformities. A year later, Paralysis due to colica pictonum was added.

These main categories remained unchanged until 1823. Gout was not included until 1865: many of the poor in the eighteenth century had very little protein in their diets, which may have contributed to these findings.

It was well known outside Bath that these records were being kept: it was mentioned earlier that Sir George Baker quoted the records of the Bath and Exeter hospitals in his famous paper on the Devonshire Colic. ${ }^{45}$ Between 1762 and 1767, 285 patients with Devonshire Colic (colica pictonum) were admitted to the Exeter hospital. Of these, 209 (73 per cent) were cured or improved. During the same period, 281 patients were admitted into the Bath hospital, of whom 259 (92.5 per cent) were cured or improved. It is worth noting that during this five-year period 20 per cent more patients were cured in Bath than in Exeter. This included some 80 patients referred to the hospital in Bath from the Exeter hospital as they had not been cured by the treatment in Exeter. Dr Andrew, the physician in Exeter, acknowledged this success in a communication to Sir George Baker. "When the disease proves obstinate we always endeavour to get our patients to the Hospital in Bath. The Bath water, though not a specific, being esteemed by us the most effectual remedy both internally and externally used."

In 1770 Dr Charleton ${ }^{47}$ published accounts of cases seen by himself and by Dr William Oliver. Included was a table showing "A State of the Paralytic Patients admitted into the Bath Hospital, from May 1751, to May 1764." A total of 1,053 cases with paralyses were admitted during this period, of which 813 were cured or had benefited from the treatment. Of the 237 cases admitted with "Palsies from Cyder and Bilious Cholics", 218 (92 per cent) were said to have benefited. There were 40 patients with "Palsies due to Metallic Effluvia", of whom 38 (95 per cent) benefited. Clearly, the Hospital physicians considered the treatment of paralysis to be a very important part of their practice, and they were aware of the value of the records that they were keeping. 48

The Annual Reports from 1760 to 1879 show comparable results. Of 3,377 cases of paralysis due to lead admitted, 1,533 (45 per cent) were cured, and 3,162 (93 per cent) were improved. Total admissions during this period of 120 years was 49,102 , of which 6.9 per cent of the cases were considered to have a paralysis due to lead. During this period, 23 per cent of all the cases admitted were said to have been cured.

\footnotetext{
"hectical", had abcesses, "or could not bear the Heat of the House". The other group was those who were "Irregular". They were "those who left the hospital at their own request or were discharged by misbehaviour, or who eloped", who therefore did not complete the full course of treatment. Charleton wished to make these distinctions very clear: by identifying those who were "improper" or "irregular" he could consider only those who "had continued in the house and made a fair trial of the waters", in which case "the evidence in their [the waters"] favour will be considerably increased". This classification was used throughout the trial.

45 Baker, 'Essay', op. cit., note 7 above, p. 38.

${ }^{46}$ Quoting Andrew, ibid., p. 39.

47 Charleton, op. cit., note 5 above, Tract 2, pp. 12-13.

48 John Spry, A practical treatise on the Bath waters, London, J. Robinson, 1822, pp. 250-1.
} 
This relatively high success rate with patients suffering from paralyses due to lead intoxication might be attributed to a highly selective admission policy or to over-optimistic assessments of the results, but if one compares the cure rate of the paralyses due to lead with those of paralyses from other causes, a marked difference is seen. This was illustrated clearly in a broadsheet ${ }^{49}$ published in 1830 , giving the 'Aggregate Amount of Patients in the Bath General Hospital' between 1799 and 1828 (figure 2). These figures were presented to show "to how great an extent their Beneficial Effects have been experienced by the Poorer Classes of this Country". On analysing the results, it can be seen that 24 per cent of all cases of paralyses were cured, but of these only 6 per cent of the paralyses due to deformities of the spine, and 11 per cent of other paralyses not due to lead (often following strokes) were cured. However, 49 per cent of the cases due to lead poisoning were discharged as cured.

\begin{tabular}{|c|c|c|c|c|c|c|}
\hline \multicolumn{7}{|c|}{ Aggregate Amount of Patients of the Bath General Eompital for 30 Years. } \\
\hline liroin $17 !(4)$ to $18: 2 x$. & Cured. & $\begin{array}{l}\text { Muct } \\
\text { Bouter. }\end{array}$ & 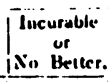 & 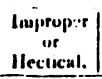 & $\begin{array}{c}\text { Notretia } \\
\text { sivur. }\end{array}$ & $11 \cdots+1$. \\
\hline$\ldots \ldots \ldots \ldots \ldots$ & 705 & 1660 & 207 & 2.51 & 40 & 19 \\
\hline 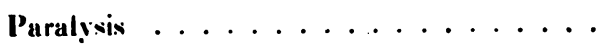 & 242 & $1: 319$ & $2 \cdot 24$ & $2 \$ 66$ & 36 & 87 \\
\hline Palsy from Colica Pictonum . . . . . . . . & 374 & 3.57 & 2 & 6 & 18 & i \\
\hline Palsy from Vertcolora of Back distorted . . & 11 & 76 & 11 & 71 & $: 3$ & I0 \\
\hline Lepra and other Discuses of the Skill. . . & 565 & 331 & 4 & 16 & 16 & i) \\
\hline $\begin{array}{l}\text { Lameness and Weakness of limbs from } \\
\text { Tumours, Contusions, Colder, de. Se. . }\end{array}$ & 259 & 517 & 60 & 181 & 11 & 1.j \\
\hline 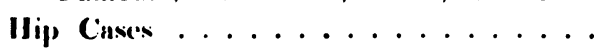 & 161 & 456 & 41 & 180 & 10 & 10 \\
\hline Biliary and Viscerul Obstructions . . . & 20 & 53 & 2 & + & ( & 0 \\
\hline
\end{tabular}

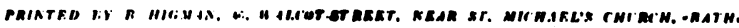

\section{Figure 2}

The differences between these cure rates indicate quite clearly that the doctors showed clinical judgement when assessing the outcome of the treatment of paralyses from different causes. In general, the historical evidence shows that Bath spa therapy was a very effective treatment of paralysis due to lead poisoning.

\section{A MODERN TRIAL OF THE WATERS}

By using modern techniques it is possible to suggest how these cures could have been achieved. Sitting in warm water up to the neck formed a vital part of the treatment in Bath, and this immersion could have contributed to the cures claimed by the Bath Hospital.

In the early 1970s Americans working on the NASA ${ }^{50}$ space programme found that it was possible to simulate the effects of weightlessness by sitting would-be astronauts

49 Hunt Collection, Bath Central Reference Library, Broadsheet 1830, vol. 1, p. 232.

so Murray Epstein, 'Renal effects of head out immersion in man', Physiol. Rev., 1978, 58(3): 529-81. 


\section{Audrey Heywood}

up to their necks in water at $35^{\circ} \mathrm{C}$. Murray Epstein was able to carry out extensive studies on the profound physiological effects of immersion on the human body. He found that, during immersion up to the neck, the urinary excretion of water, sodium, and calcium were markedly increased.

The body sitting or standing in water is exposed to external pressure from the surrounding water. The water pressure increases with depth so that the legs and abdomen are compressed, expelling blood and some interstitial fluid; this extracellular fluid moves into blood vessels in the thorax, producing an increase in central blood volume of about $700 \mathrm{mls}$. The consequent rise in right and left atrial pressures is the stimulus that leads to the large increases in urinary volume and sodium excretion that are observed during immersion up to the neck (figure 3 ). This is because sensory receptors for blood volume are apparently situated in the right atrium, so this relative central hypervolaemia deceives the body, which reacts as though there had been an increase in total body fluid volume, not just a re-allocation of fluid. The exact mechanism by which these changes are brought about are not clear, but there are certainly profound alterations in humoral function. Plasma renin activity and aldersterone levels are substantially suppressed by immersion, and the level of plasma atrial natriuretic peptide (ANP), a hormone produced in the right atrium, has been shown to rise during immersion. ${ }^{51}$ The fall in plasma noradrenaline

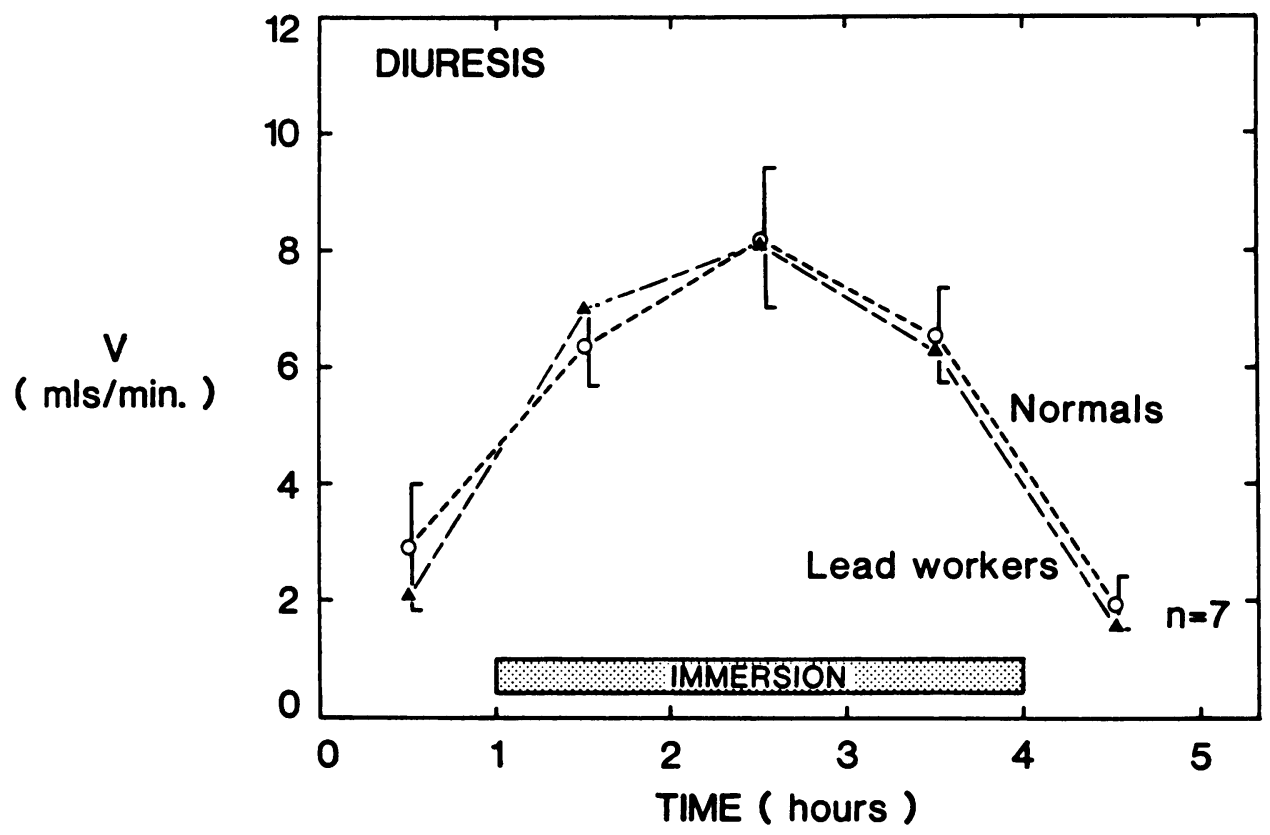

Figure 3

51 J. Anderson, N. Millar, and others, 'Atrial natriuretic peptide. Physiological release associated with natriuresis during water immersion in man', Clin. Sci., 1986, 71: 319-22. 
levels on immersion suggests a suppression of sympathetic activity that may modify kidney function. It is likely that it is a combination of the above changes, that is the effective mechanism.

During head-out water immersion the cardiac output is increased (50 per cent at $35^{\circ} \mathrm{C}$ ) but there is no rise in blood pressure, so the resistance of the peripheral circulation must be reduced.

The increase of ANP hormone is thought to act directly on the kidney tubules, increasing the loss of water and sodium. The reduction of noradrenaline levels during immersion is possibly one reason that bathing in warm water is found to be so relaxing.

These immersion studies ${ }^{52}$ indicate some of the mechanisms involved in the bathing element of spa therapy, and that will be evoked by immersion in any water at $35^{\circ} \mathrm{C}$. They also suggest an explanation for some of the traditional contra-indications to spa therapy: recent cardiac infarction and pulmonary disease.

By using these immersion techniques it is possible to suggest how the high cure rates for lead poisoning claimed for Bath spa therapy could have been achieved. Sitting in warm water up to the neck formed a vital part of the treatment in Bath. Immersion has been shown to increase urinary water and sodium loss and also increases urinary calcium excretion. As the human body handles calcium and lead in a similar way, it was thought possible that up-to-the-neck immersion would also increase urinary lead excretion. When experiments were set up in the Immersion Laboratory in the Bristol Royal Infirmary to test this hypothesis, we were able to confirm Epstein's findings and to establish that urinary lead excretion is increased during immersion. ${ }^{53}$

Lead poisoning is very rare these days, but mild levels of intoxication are occasionally found in lead workers. In Bristol there is a traditional Shot Tower and we were able to recruit three workers from there who volunteered to take part in our experiments. They were all symptom-free, with blood-lead levels below the legal safety requirements, but significantly higher than those of the normal population. They had a very much lower total body-lead load than the patients admitted to the Bath Hospital with lead paralyses in the eighteenth century.

The three lead workers were immersed for three hours up to their necks in water at $35^{\circ} \mathrm{C}$. They also sat outside the tank for one hour before and after the immersion. Blood samples were taken before immersion, and samples of urine collected hourly for the five hours of the experiment.

In effect, we measured urinary lead excretion basally and during a three-hour immersion period. In all the subjects so far examined there was a large increase in the rate of urinary lead excretion during immersion, greatest during the second hour of immersion $^{54}$ (figure 4).

\footnotetext{
52 Paul O'Hare, A. Heywood, and others, 'Observations on the effects of immersion in Bath Spa water', Br. med. J., 1985, 291: 1747-51.

${ }^{53}$ Audrey Heywood, A. Waldron, and others, 'Effect of immersion on urinary lead excretion', Br. J. indust. Med., 1986, 43: 713-15.

54 Ibid. The mean total amount of lead $(\mu \mathrm{g})$ excreted in the urine for each hour during immersion were: pre-immersion, 5.85; hour 1, 9.79; hour 2, 24.25; hour 3, 15.0 .
} 


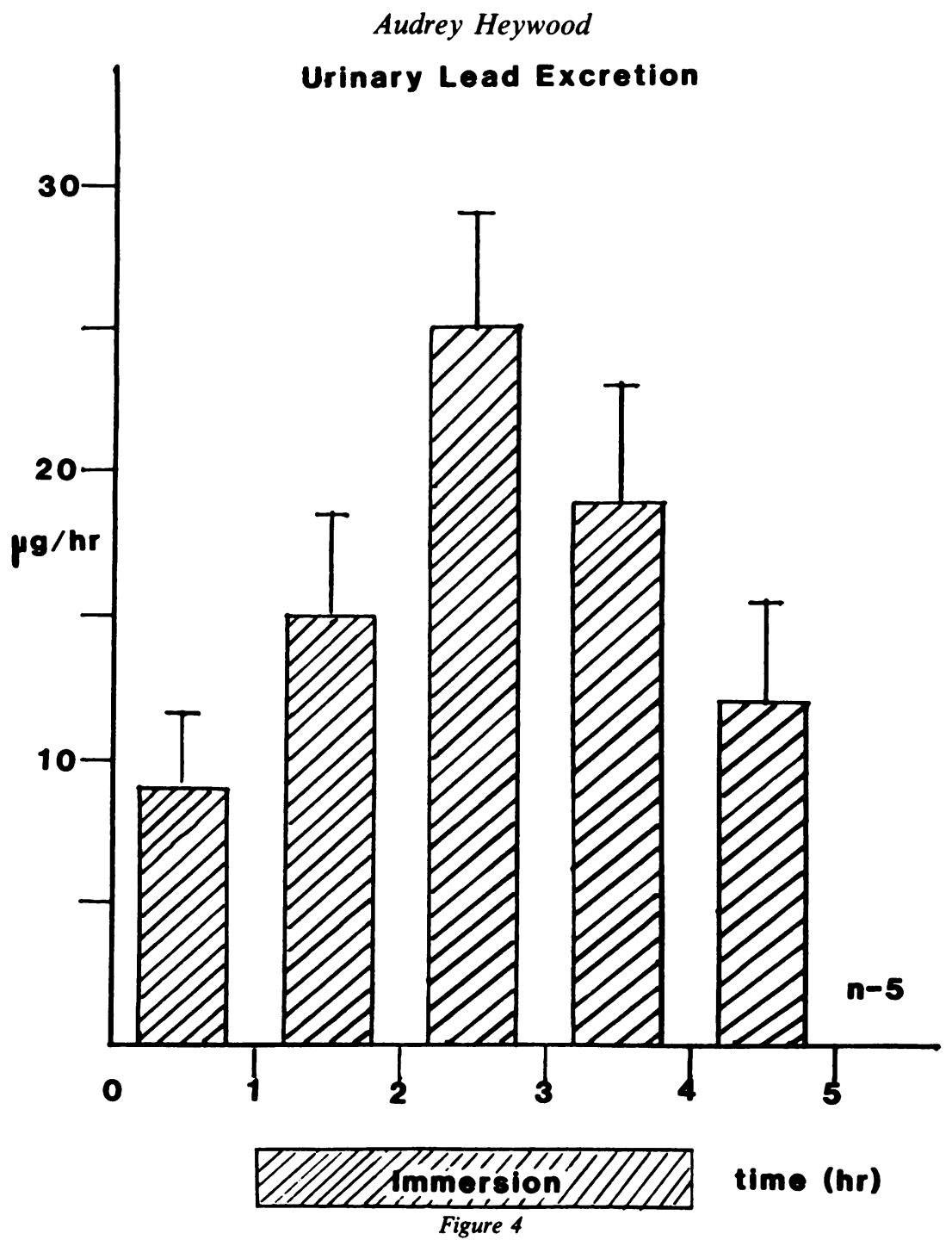

The total amounts excreted during one three-hour immersion period are small compared to the total body lead, which is predominantly tissue-bound. However, if these immersions were continued to the extent described in the Bath Hospital records, i.e. three times a week for 24 weeks, an appreciable proportion of the total body lead would be removed. We can therefore suggest that this was a mechanism through which traditional Bath spa therapy could have operated.

It is essential, however, that we do not disregard the other elements involved in Bath spa treatment, which included removal from the source of exposure to lead, good food, and the exercise of wasted muscles in a large volume of warm water. Nor should we disregard the possible therapeutic effects of drinking the mineral water, of which the patients drank about $1 \frac{1}{2}-2$ pints a day. The Bath mineral water has a high 


\section{A trial of the Bath waters}

calcium content and an appreciable iron level if the water is drunk soon after it arises from the spring. The water contains $390 \mathrm{mgm}$ of calcium per litre, the suggested daily dose for an adult. Iron is present in a soluble form as the water rises from the source, but after exposure to the oxygen in the atmosphere the ferrous salt is changed into the insoluble ferric form and is precipitated. This produces the characteristic orange coloration around the spring. Work done in North America ${ }^{55}$ in the 1970 s has shown that calcium and iron deficiency increases the amount of lead that is absorbed and retained by the body and increases the toxicity of that already in the body. ${ }^{56} \mathrm{~A}$ recent American report has suggested giving calcium and iron supplements to deprived infants with raised blood-lead levels. So, drinking the Bath water could be helpful too, although the effects are yet to be studied: the eighteenth-century doctors certainly thought it to be an important part of the therapy.

The founders of the Bath Hospital believed that by meticulously collecting and recording their results it would eventually be possible to use their "indisputable evidence" to show that the Bath Spa therapy could be recognized as an effective cure, not merely a pleasant experience. This paper is an attempt to justify their endeavours in the case of chronic lead poisoning.

${ }^{55}$ K. Mahaffey, R. Goyer, and others, 'Dose response to lead ingestion in rats fed low dietary calcium', J. lab. clin. Med., 1973, 82: 92-100.

$56 \mathrm{~J}$. Barton and others, 'Effects of iron on the absorption and retention of lead', ibid., 1978, 92: $536-47$. 